Claremont Colleges

Scholarship@ Claremont

CGU Faculty Publications and Research

CGU Faculty Scholarship

$1-1-2008$

\title{
Women and Technology: Reversing the Trends of Attrition and Obtaining a Balance
}

Gondy Leroy

Claremont Graduate University

Kristin M. Tolle

Microsoft

Linda Perkins

Claremont Graduate University

\section{Recommended Citation}

G. Leroy, K. M. Tolle, L. Perkins, "Women and Technology: Reversing the Trends of Attrition and Obtaining a Balance", Women's Studies, 37, 173-175, 2008.

This Article is brought to you for free and open access by the CGU Faculty Scholarship at Scholarship @ Claremont. It has been accepted for inclusion in CGU Faculty Publications and Research by an authorized administrator of Scholarship @ Claremont. For more information, please contact scholarship@cuc.claremont.edu. 
This article was downloaded by: [Claremont Colleges Library]

On: 26 March 2012, At: 11:49

Publisher: Routledge

Informa Ltd Registered in England and Wales Registered Number: 1072954

Registered office: Mortimer House, 37-41 Mortimer Street, London W1T 3J H, UK

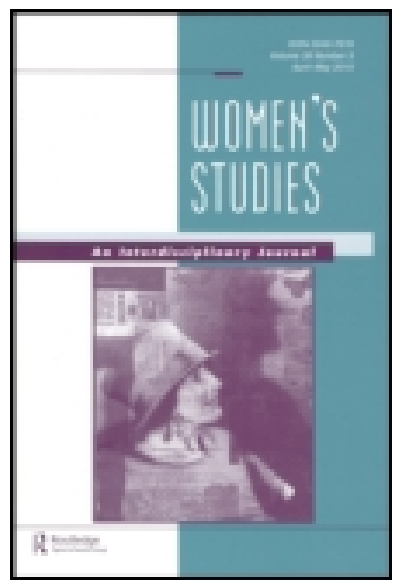

\section{Women's Studies: An inter- disciplinary journal}

Publication details, including instructions for authors and subscription information:

http:// www. tandfonline.com/loi/ gwst20

Women and Technology: Reversing the Trends of Attrition and Obtaining a Balance

GONDY LEROY ${ }^{a}$, KRISTIN M. TOLLE $^{b} \&$ LINDA PERKINS $^{c}$

${ }^{a}$ Assistant Professor, School of Information Systems and Technology, Claremont Graduate University, Claremont, California, USA

${ }^{\mathrm{b}}$ Program Manager for Biomedical Computing, External Research @ Microsoft Research, Redmond, Washington, USA

c University Associate Professor and Director of Applied Women's Studies, Claremont Graduate University, Claremont, California, USA

Available online: 08 Apr 2008

To cite this article: GONDY LEROY, KRISTIN M. TOLLE \& LINDA PERKINS (2008): Women and Technology: Reversing the Trends of Attrition and Obtaining a Balance, Women's Studies: An inter-disciplinary journal, 37:3, 173-175

To link to this article: http:// dx. doi.org/ 10.1080/00497870801916996

\section{PLEASE SCROLL DOWN FOR ARTICLE}

Full terms and conditions of use: http://www.tandfonline.com/page/termsand-conditions 
This article may be used for research, teaching, and private study purposes. Any substantial or systematic reproduction, redistribution, reselling, loan, sub-licensing, systematic supply, or distribution in any form to anyone is expressly forbidden.

The publisher does not give any warranty express or implied or make any representation that the contents will be complete or accurate or up to date. The accuracy of any instructions, formulae, and drug doses should be independently verified with primary sources. The publisher shall not be liable for any loss, actions, claims, proceedings, demand, or costs or damages whatsoever or howsoever caused arising directly or indirectly in connection with or arising out of the use of this material. 


\title{
WOMEN AND TECHNOLOGY: REVERSING THE TRENDS OF ATTRITION AND OBTAINING A BALANCE
}

\author{
GONDY LEROY \\ Assistant Professor, School of Information Systems and Technology, \\ Claremont Graduate University, Claremont, California
}

\section{KRISTIN M. TOLLE}

Program Manager for Biomedical Computing, External

Research @ Microsoft Research, Redmond, Washington

\section{LINDA PERKINS}

University Associate Professor and Director of Applied Women's Studies, Claremont Graduate University, Claremont, California

Many reports and technical news bulletins presented by organizations such as the National Science Foundation (NSF), the Institute of Electrical and Electronics Engineers (IEEE), the Association for Computing Machinery (ACM), and the National Center for Women \& Information Technology (NCWIT) highlight that few female and minority college students are choosing science, technology, engineering, and math (STEM) fields of study or careers. For those who choose STEM fields, attrition both during education and in the workplace is pervasive. NSF reports in its 2006 Science Indicators that women account for only $27 \%$ of the bachelor's degrees in computer sciences. And although the percentage of women occupied in science and engineering increased from $23 \%$ in 1993 to $27 \%$ in 2003 , only $11 \%$ of the engineers are women. For computer science occupations in particular there was a $2 \%$ decline.

Assumptions of the past two decades regarding the absence of girls and women in the field of computer science based on the

Address correspondence to Gondy Leroy, 130 E. Ninth Street, Claremont, CA 91711. Email: gondy.leroy@cgu.edu 
notion of unequal access are no longer valid. Recent research indicates that the gap between genders and access to computers has closed and participation of boys and girls in computer usage has nearly reached the level of parity. Research within the Information Technology community as well as the women and feminist studies community are now producing more in depth and theoretical studies on the decline of women and girls participation in IT. An important source on this topic is the recent book edited by J. McGrath Cohoon and William Aspray, Women and Information Technology: Research on Underrepresentation (2006) in which an examination of the obstacles and issues from girls to women in higher education are explored. Issues related to racial disparities as well as workplace issues were discussed.

Attitudes towards the field of IT are shaped early in girls' lives. Computer companies professing to be supportive of women in computing are also the same companies that provide more male targeted applications (e.g., game makers produce far more titles aimed at boys than girls). Often girls opt out of technical fields because they feel that they are less experienced and will be at a disadvantage as a result of a lack of early exposure. The antisocial "geek" image associated with computer scientists is a much stronger deterrent to women than men. Studies have shown that issues such as school curriculum and course selection, relationships with teachers, availability and uses of computers in girls' homes and schools, family, community and peer attitudes, and single-sex schools are important variables in shaping girls' confidence and aspirations for IT fields (Cohoon and William, 2006).

With this special issue, we continue the discussion and present essays that provide recent research on gender and IT from an international as well as local perspective. The first essay by Soe and Yakura, "What's Wrong with the Pipeline? Assumptions about Gender and Culture in IT Work," reviews existing work. The authors analyze the popular pipeline metaphor, which is often used to describe women's attrition from technical fields, and discuss how the metaphor needs augmentation. The authors emphasize the need for taking IT culture into account.

In "Women's Adaptation to the IT Culture," Guzman and Stanton performed research focusing on potential cultural differences in the workplace. Their essay describes the results of a large study of 27 interviews and a survey administered to 215 
participants. As a result they are able to show how occupational culture influences occupational commitment for women.

Herring and Marken, the authors of "Implications of Gender Consciousness for Students in Information Technology," look at an earlier sector of subjects by focusing on gender consciousness among IT students. They conducted 136 interviews to evaluate gender consciousness and describe its relation to two self-efficacy measures: self-confidence and ambition.

In their essay, "The Only Person Who Cares": Misperceptions of Mentoring among Faculty and Students in IT Programs," Ogan and Robinson study a combination of students and their faculty. They conducted a survey to evaluate the role of mentoring by and for women and found a disconnect between faculty and student perceptions of mentoring.

We close our special issue with Sappleton and Takruri-Rizk's essay, "The Gender Subtext of Science, Engineering, and Technology (SET) Organizations: A Review and Critique," which reviews the existing literature and presents different possible explanations for the current under-representation of women in IT. It is our hope that this essay as well as the previous ones broadens understanding of this important topic and opens the door for future publications and special issues. 